\title{
KRT72 wt Allele
}

National Cancer Institute

\section{Source}

National Cancer Institute. KRT72 wt Allele. NCI Thesaurus. Code C105683.

Human KRT 72 wild-type allele is located in the vicinity of $12 q 13.13$ and is approximately $16 \mathrm{~kb}$ in length. This allele, which encodes keratin, type II cytoskeletal 72 protein, is involved in the formation of hair. 